\title{
Chemical and Fatty Acid Compositions of Date Palm Fruit (Phoenix dactylifera L) Flour
}

\author{
H. N. Ogungbenle \\ Chemistry Department, University of Ado - Ekiti, P. M. B. 5363, Ado - Ekiti, Nigeria.
}

\begin{abstract}
The proximate, sugar, minerals and fatty acids composition of date palm fruit were determined. The moisture content is $5.24 \pm 0.05 \%$, ether extract value is $1.54 \pm 0.01 \%$, crude fibre content is $4.34 \pm 0.03 \%$, crude protein content is $4.94 \pm 0.04 \%$ while the value of carbohydrate is $80.87 \pm 0.05 \%$. The fractions of sugar contained maltose $(33.7 \mathrm{mg} \%)$, fructose $(22.8 \mathrm{mg} \%)$ and glucose $(22.3 \mathrm{mg} \%)$. The most abundant minerals in the sample is potassium with the value of $710.0 \mathrm{mg} \%$ sample. The most concentrated fatty acids were oleic acid (44.51g/100g) $>$ palmitic acid $(23.05 \mathrm{~g} / 100 \mathrm{~g})>$ linoleic acid $(11.66 \mathrm{~g} / 100 \mathrm{~g})$. All these quality food properties make it good source of unsaturated fatty acids and sweetening agent in food processing industry.
\end{abstract}

Key words: Carbohydrates, Fatty acids, Minerals, Fruit flour.

\section{Introduction}

Date palm fruit (Phoenix dactylifera $\mathrm{L}$ ) is one of the earliest crops and is widely cultivated in Arabia, India, tropical and subtropical regions. The fruit is ovoid shaped and the pericarp is soft and sugary. It contains high level of sugar content, essential vitamins and high nutrient density. Apart from it's nutritional significance, it is medicinally good for ulcer patients (Duke, 1981). Date palm is propagated by seed and the seedlings are first planted in rows and later transplanted into the permanent farmland. In view of the present rate of population growth in developing countries, date palm fruit may be more useful in some food formulations than for direct consumption after cooking/roasted.

The use of any seed as a source of nutritious food arises from the knowledge of the chemical composition of its flour and other products (Young and Scrimshaw, 1979; Ogungbenle, 2003; Akobundu et al, 1982). The present study was undertaken to report the proximate minerals, carbohydrate and fatty acids composition of date palm fruit flour.

\section{Materials and Methods}

The date palm fruit (Phoenix dactylifera $\mathrm{L}$ ) was bought in a market in Kano, Kano State of Nigeria. The fruits were thoroughly screened to eliminate the bad ones and the remaining

\footnotetext{
*Corresponding author: E-mail: httphenryo@yahoo.com
}

good ones were washed and dried. The dried date palm fruits were stored in a container and kept in freezer until used.

\section{Proximate Analysis}

The proximate analysis of the sample for total ash, crude fibre and ether extract were carried out using the methods described in AOAC (1990). The nitrogen was determined by Micro Kjedahl method described by Pearson (1976) and the nitrogen content was converted to protein by multiplying by 6.25. Carbohydrate was determined by method of difference.

\section{Mineral Analysis}

The minerals were analysed by dry ashing the sample at $550^{\circ} \mathrm{C}$ to constant weight and digested with $3 \mathrm{M} \mathrm{HCI}$ solution. Sodium and potassium were determined by using a flame photometer (model 405, Absorption Spectrophotometer (Perkin Elmer Model 403, USA).

\section{Sugar Analysis}

The sugar in the sample was determined by the method of Shaffer-Somogyl sugar thiosulfate equivalents, which was described in AOAC (1990). The amount of sugar was calculated according to Shaffer-Somogyl's equation. For example, 
glucose, heating time was 15 minutes, $Y=0.1099 x+0.048$ where $\mathrm{Y}=\mathrm{mg}$ sugar in $5 \mathrm{ml}$ and $\mathrm{X}=$ titre value.

\section{Fatty acid Analysis}

Oil from the date palm fruit was extracted by the soxhlet extraction using petroleum ether. The oil extracted was converted to methyl ester using the method described by Hall (1982). The fatty acid methyl ester was analysed using Pye Unicam 304 gas chromatography (Pye Unicam, Cambridge, UK).

\section{Results and Discussion}

Table I presents the proximate composition of the sample. The flour has a high level of carbohydrate $(80.67 \%)$ and low fat content $(1.54 \%)$. The protein is moderate and known to be rich in both glutamic and aspartic acids. The ash content is $3.27 \%$. This result is in good agreement with an acceptable ash range mean values of legumes which are between 2.4 $5.0 \%$ (FAO, 1989). This may indicate that date palm fruit would likely contain very high qualities essential minerals. Since ash content is an index to evaluate and grade the nutritive quality of foods (Pearson, 1976). The value of crude fibre is $4.34 \%$. Dietary fibre is known to influence digestion and absorption processes in the small intestine (Cherbut et al, 1995; ASP, 1996). Legumes are known to contain appreciable amount of fibre (Salunkhe et al, 1985). The present result indicates that date palm fruit has crude fibre that is higher than the value reported by Oshodi et al. (1999) for pearl millet (1.8\%) and those varieties of African yam bean (1.61-2.38\%) reported by Adeyeye (1997). Since the crude fibre value of date palm fruit is moderately high, if consumed will aid digestion and absorption processes in the small intestine.

Table I: Proximate composition of date palm fruit flour (Phoenix dactylifera L)

\begin{tabular}{l|c}
\hline Component & $\%$ \\
\hline Moisture & $5.24 \pm 0.05$ \\
Crude protein & $4.94 \pm 0.04$ \\
Ether Extract & $1.54 \pm 0.01$ \\
Ash & $3.27 \pm 0.02$ \\
Crude fibre & $4.34 \pm 0.03$ \\
Carbohydrate (by difference) & $80.67 \pm 0.05$ \\
\hline
\end{tabular}

Table II presents the mineral content. The most abundant mineral was potassium, $711.0 \mathrm{mg} \%$ sample. This observation is in close agreement with the reported observations of
Aletor and Aladetimi (1989), Olaofe and Sanni (1988) and Oshodi et. al. (1999). The present value is comparable with those reported by Olaofe and Sanni (1988) for some selected agricultural grain products i.e. Soy bean, Cowpea, Maize and Sorghum (644 - $4510 \mathrm{mg} / 100 \mathrm{~g})$. This shows that potassium-rich chemical fertilizer would be needed for planting in Nigeria to replace the macro-uptake of potassium by plants and keep the fertility of the soil.

Table II: Mineral content of Date palm fruit flour (Phoenix dactylifera $\mathrm{L}$ )

\begin{tabular}{l|c}
\hline Minerals & $\mathrm{mg} \%$ \\
\hline Sodium & $342.5 \pm 0.3$ \\
Potassium & $711.0 \pm 0.2$ \\
Calcium & $34.00 \pm 0.1$ \\
Magnesium & $27.27 \pm 0.03$ \\
Zinc & $29.39 \pm 0.01$ \\
Iron & $3.68 \pm 0.5$ \\
Copper & $0.44 \pm 0.8$ \\
Phosphorus & $42.96 \pm 0.2$ \\
Lead & n.d \\
Nickel & n.d \\
Cobalt & n.d \\
$\mathrm{Na} / \mathrm{K}$ & 0.48 \\
$\mathrm{Ca} / \mathrm{P}$ & 0.79 \\
\hline
\end{tabular}

The sample is found to be good sources of $\mathrm{Na}, \mathrm{Mg}, \mathrm{K}, \mathrm{Ca}, \mathrm{P}$ and $\mathrm{Fe}$, while $\mathrm{Co}, \mathrm{Pb}$ and $\mathrm{Ni}$ were not detected in the sample. $\mathrm{Cu}$ is detected, but occurred at low level. Modern diets which are rich in protein and phosphorus may promote loss of calcium in the urine (Shill and Young, 1988). This has led to the concept of the $\mathrm{Ca} / \mathrm{P}$ ratio. When $\mathrm{Ca} / \mathrm{P}$ is low, abnormal quantity of calcium is lost in the urine. Thereby reducing the level of calcium in the body. According to Niemann et. al (1992) which stated that food is considered "good" when the ratio is greater or equal to one and "poor" when the ratio is less than 0.5 . This implies that date palm fruit is nutritionally good food $(\mathrm{Ca} / \mathrm{P})$ ratio $=0.79)$. The presence $\mathrm{Na} / \mathrm{K}$ in the body is useful for intercellular activities, maintenance of the osmotic balance of the body fluid, protect the body from excessive fluid loss and involved in the contraction of muscle cells and impulse conduction along nerve fibres (Lake and Waterworth, 1980). $\mathrm{Na} / \mathrm{K}$ in the body is also useful in the prevention of high blood pressure. $\mathrm{Na} / \mathrm{K}$ ratio 0.60 is recommended for an hypertensive patient (Niemann et al, 1992). It is interesting that the value for date palm (0.48) is 
not higher than 0.6 which indicate that it would inhibit high blood pressure. The sample studied is fairly rich in iron and iron is highly useful for the formation of blood.

Table III presents the sugar contents of the sample $(\mathrm{mg} \%)$. Maltose was found to be the richest sugar in date palm fruit with the value $33.7 \pm 0.5 \mathrm{~m} \%$ sample and is moderately low in L - Arabinose. Maltose is a disaccharide, which is contained in malted drinks and malted loaves. It implies the sample studied may be useful in weaning foods and beverages / drinks industries, since it is rich in maltose. The sample is rich in sugar, glucose $(20.3 \mathrm{mg} \%)$, fructose $(20.8 \mathrm{mg} \%)$ and L-sorbose (23.6mg sugar/100g sample). This is in good agreement with the earlier observation of Duke (1981) that date fruit/pericarp is fleshy and sugary (Duke,1981).

Table III: Carbohydrate composition of Date palm fruit flour (Phoenix dactylifera $\mathrm{L}$ )

\begin{tabular}{l|c}
\hline Sugar & $\mathrm{mg}^{\circ}$ \\
\hline Glucose & $20.3 \pm 0.1$ \\
Fructose & $20.8 \pm 0.2$ \\
Maltose & $33.7 \pm 0.5$ \\
D- Xylose & $17.0 \pm 0.1$ \\
D-Mannose & $11.5 \pm 0.2$ \\
L-Arabinose & $10.5 \pm 0.1$ \\
L-Sorbose & $23.6 \pm 0.3$ \\
\hline
\end{tabular}

Glucose and fructose are the principal dietary monosaccharides derived from fruits, berries and sweetened drinks (Southgate, 1995). The importance of the blood glucose response after a meal, often expressed as the glycaemic index (GI). In maturity onset diabetes, low GI foods improve the metabolic (Brand miller,1994; ASP, 1996) and a numder of potential advantages of low GI foods are currently being explored (Truswell,1992). Such conceivable advantages include longer satiety, low blood pressure (caused by diabetes). The levels of glucose and fructose in date palm fruit which is fairly high may hinder it's recommendation for diabetics patients. The nutritional quality can be improved by diluting its natural sweetness and combine with milk products.

Table IV presents the fatty acid composition of the sample. In the results, the saturated acids are lauric $\left(\mathrm{C}_{12: 0}\right)$, myristic $\left(\mathrm{C}_{14: 0}\right)$, palmitic $\left(\mathrm{C}_{16: 0}\right)$ and stearic $\left(\mathrm{C}_{18: 0}\right)$; the monosaturated is oleic $\left(\mathrm{C}_{18: 1}\right)$, while polyunsaturated is linoleic $\left(\mathrm{C}_{18: 2}\right)$. The result shows that oleic acid has the highest value with $44.81 \mathrm{~g} / 100 \mathrm{~g}$, palmitic acid is second with $23.05 \mathrm{~g} / 100 \mathrm{~g}$ and linoleic acid is in the third position with $11.66 \mathrm{~g} / 100 \mathrm{~g}$. This trend agrees with that reported by Morton (1987) for the variety of date flour. It has been shown that linoleic and oleic acids are the major fatty acids in legumes. Many lipids from legume seeds contain substantial amounts of saturated fatty acids, especially palmitic acid (Lee and Mattick,1961). A higher proportion of either linoleic or linolenic acid is associated with legumes containing insignificant amounts of lipids (Salunkle et al.,1985), Oleic, palmitic and linoleic acids are more concentrated in date palm fruit. The values of oleic and palmitic acids presently reported are higher than that reported for Adenopus breviflorus $(9.31 \%, 10.19 \%)$ by oshodi (1992) and $0.21 \%, 19.04 \%$ reported for African yam bean by Adeyeye et al. (1999).

Table IV: Fatty acids composition of Date palm fruit flour (Phoenix dactylifera $\mathrm{L}$ )

\begin{tabular}{l|c}
\hline Fatty acids & $\%$ \\
\hline Lauric $\left(\mathrm{C}_{12: 0}\right)$ & 8.15 \\
Myristic $\left(\mathrm{C}_{14: 0}\right)$ & 5.36 \\
Palmitic $\left(\mathrm{C}_{16: 0}\right)$ & 23.05 \\
Stearic $\left(\mathrm{C}_{18: 0}\right)$ & 9.42 \\
Oleic $\left(\mathrm{C}_{18: 1}\right)$ & 44.81 \\
Linoleic $\left(\mathrm{C}_{18: 2}\right)$ & 11.66 \\
\hline
\end{tabular}

Linoleic acid is the most important essential fatty acids required for growth, physiological functions and body maintence (Salunkhe et al, 1985). Date palm fruit oil would serve the same functions in the body.

\section{Conclusion}

This study revealed that the date palm fruit flour could be potential food supplement near future due to its high quantities of minerals, carbohydrates and unsaturated fatty acids.

\section{References}

Adeyeye E. I. (1997). Amino acid composition of six varieties of dehulled African yam been flour Int. J. fd. Sci. Nutr. 48: 345-351.

Adeyeye E. I., Oshodi A. A. and Ipinmoroti K. O. (1999). Fatty acid compodition of six varities of dehulled African Yam bean flour Int. J. Fd sci. Nutri. 50 : 357365.

Akobundu E. N. T, Cherry J. P. and Simons J. G. (1982). Chemical, functional and nutritional properties of egusi 
seed protein products. $J$. food Sci.,47: 829-835.

AOAC (1990). Offcial methods of Analysis, 15th edn. Washisigton, DC. Association of official Analytical chemists.

Aletor V. A. and Aladetimi O. O. (1989). Compositional evaluation of some cowpea varieties and some inderutilred edible legures. Die Nalrung 10: 999-1007.

Asp. N. G (1996). Dietary Canbohydrate: Classification by chemistry and physiology. Food Chem. 7(1): 9-14.

Brand miller J. C. (1994) Importance of glycaemic index in diabetes. Am. J. Clin. Nutr., 59: 747s-752s.

Cherbut C., Barry J. L., Lairon D. and Dirand M. (eds) (1995). Dietary fibre. Mechanisms of Action in Human physiology and metabolism. John Libbey EUROTEXT, Paris.

Duke J. A. (1981) Hand book of Legumes of world Economic importance. Plenum press, New York, pp 33.

FAO (1989). Utility of Tropical foods: Tropical beans. Food and Agricultural organizaton publication pp 22-26.

Hall G. M. (1982). Silage from tropical fish. Lipid behavior. J. food Technol. 21: 45-54.

Lake B. and Waterworth M. (1980). Foods and Nutrition. London mills and Boon Ltd.

Lee F. A. and Mattick L. R. (1961). Fatty acids of the Lipids of vegetables. I. Peas (Pisum sativum). J. food Sci, 26: 273-275.

Morton J. (1987). Date II-In Fruits of warm climates. J. F. Morton, Miami, F. L. Nieman D. C, Butter worth D. E. and Niemana C. N. (1992). Nutition. Wine. Brown publishers Dubugue, USA.Pp 237-312.
Ogungdenle H. N. (2003). Nutritional evaluation and functional properties of quinoa flour. Int. J. food sci.Nutr. 54: $153-158$

Olaofe O. and Sanni C. O. (1985) Mineral Cotents of agricultural products. Food Chem. 30: 73-77.

Oshodi A. A., Ogungbenle H. N. and Oladimeji M. O. (1999). Chemical composition, nutritionally valuable minerals and functional properties of benniseed, pearl millet and quinoa flour. Int. J. fd. sci. nutr. 50: 325 331.

Pearson D. (1976). Chemical Analysis of foods, 6th edu,pp.6-9. London, Churchill.

Salunche D. K., Kadem S. S. and Chavan J. K. (1985). CRC post harvest Blotechnology of food legmes. Boca raton, FL. CRC Press.

Shill M. E. G and Young V. R. (1988). Modern nutrition in health and disease. In Nitrition Nieman, D.C. Butterworth D. E. Nieman, C. N. (eds), Wine. Brow publishers Dubugene, U S A pp 276-282.

Southgate D. A. T. (1995). Digestion and metabolism of sugers, Am.J. Clim Nutr., 62: 203s-210s.

Truswell A. S. (1992). Glycaemic index of food Eur. J. Clin. Nutri.,46 : s91-s 101.

Young V. R. and Scrimshaw N. S. (1979). Soybean protein in human nutrition : An overview. J. Am. Oil chem. Soc., 56: $110-120$.

Received: Octorber 06, 2009;

Accepted : November 05, 2009 